\title{
Probing the Structural Requirement of 7-Azabicyclo[2.2.1]hept-2-ene that Functions as Wip1 Inhibitor
}

\author{
Suhkmann Kim, ${ }^{\dagger}$ Eun Sik Pak, Jong Sung Jin, Mi Sook Won, Jang-Su Park, ${ }^{\dagger}$ Shin Won Kwang, and Jeong-Kyu Bang ${ }^{\star}$ \\ "Department of Chemistry, Pusan National University, Busan 609-735, Korea \\ Korea Basic Science Instifute (KBSI), Busan 609-735, Korea. "E-mail: bangik@kbsire.kr \\ Received Mav 12, 2008
}

Key Words : Wip 1, 7-Azabicyclo[2.2.1]hept-2-ene, Solid support, p53

The phosphatase Wipl(also called $\mathrm{PP} 2 \mathrm{C} \delta$ ) indirectly suppresses the activity of the tumor suppress protein $\mathrm{p} 53$.' $^{\prime}$ After DNA damage, such as ionizing radiation, UV light, IR or $\mathrm{H}_{2} \mathrm{O}_{2}$, several cellular pathways combine to increase the activity of $\mathrm{p53}$, which in turn controls cell cycle arrest and apoptosis. Within the network of 053 activation, Wipl inactivates $\mathrm{p} 38 \mathrm{MAP}$ kinase via dephosphorylation of a phosphothreonine. p53 Activity depends on phosphorylation of ser 33 and ser 46 by p38 MAP kinase. In order to phosphorylate p53, p38 MAP kinase first needs to be phosphorylated on Thr 180 by MKK. Therefore, Wipl controls a negative feedback loop within the p38 MAP kinase-p53 signaling pathway. ${ }^{2}$ Wip1 is overexpressed in several type of cancer including brest cancer, adenocacinoma and neuroblastoma, and turmors in which Wipl is overexpress frequently contain wild-type p53. The data accumulated about the biological functions of Wipl indicate that inhibition of its enzymatic activity could be an effective strategy for combating certain type of cancer. ${ }^{3}$

Recently, The types of inhibitors of Wipl include peptide and cyclic peptide-based molecule, an organomercuric compound, and an electrophilic molecule that is a strong Michael acceptor. ${ }^{+}$One of the best inhibitors is a MpSIpYVA). However, peptides are sensitive to protease, which could be a significant drawback in the development of therapeutics to treat cancer.

In this study, we report the design, synthesis, and characterization of a small, drug-like, molecular scaffold for the inhibition of Wipl. The reported solution structure of one of cyclic peptide inhibitors of Wipl, indicated that a highly-substituted 7-azabicyclo[2.2.1] heptane-based scaffold could arrange the key groups into a similar three-dimensional orientation (Figure 1). Specifically, groups mimicking the phosphotyrosine, phosphoserine, and isoleucine residues of $\mathrm{a}(\mathrm{MpSIpYVA})$ needed to be present on the new scaffold. The solution structure of this cyclic peptides in Figure 1B indicated that the two polar groups bearing phosphates should point approximately $180^{\circ}$ away from one another and the two hydrophobic groups should similarly be oriented

Abbreviations: HPLC: high performance liquid chromatography, DIEA: $N N$-diisopropylethylamine, TFA: trifluoroacetic acid, THF: tetrahydrofuran, NMP: $N$-methyl-2-pyrtolidone, ESI-MS: electrospay ionization mass spectrometry, 'H NMR: proton nuclear magnetic resonance spectra $180^{\circ}$ away from one another, but on an axis perpendicular to the one defined by the phosphate groups. Therefore, 7azabicyco[2.2.1]hepane-based molecules of the type shown in figure $\mathrm{C}$ represent the scaffold we chose for development of a small molecule inhibition of Wip1.

The [4+2] cycloaddition reaction between pyrroles and dienophiles has been shown to be a method for the synthesis of the 7-azabicyclo[2.2.1]hept-2-ene derivatives. ${ }^{5}$ Scheme 1 shows a typical synthetic route for the 7-azabicyclo[2.2.1]hept-2-ene derivatives. To make the pyrrole derivatives, a synthetic route based on the work by Jung and coworkers was developed. ${ }^{6}$ Initially, $\beta$-ketoamides 3 were synthesized on solid support by the combination of Rink amide resin 1 with diketene 2. Next, addition of an amine $\mathbf{4}$ to form an enaminone 5 on solid support, followed by addition of an $\alpha, \beta$-unsaturated nitroalkene 6 resulted in pyrrole formation on solid support 7 . The product resin 7 was treated with $\mathrm{TFA} / \mathrm{H}_{2} \mathrm{O}(95: 5)$ to afford the pyrrole derivatives 8 . However, pyrrole is a poor diene for the [4+2] cycloaddition reaction and usually reacts with alkenyl and acetylenic dicarboxylic acid derivatives to give Michael addition products ${ }^{7}$. On the other hand, the synthesis of 7-azabicyclo[2.2.1]hept-2-ene via benzyne formation has been examined by Caster et al. ${ }^{8}$ The hypervalent iodine compound, (phenyl)[2-(trimethylsilyl)phenyl]iodonium triflate 9 , which is an excellent precursor of benzyne, was prepared in two steps from 1,2dichlorobenzene. 1,2-bis(trimethylsilyl)benzene was prepared by bis-(trimethylsilyl)ation of 1,2-dichlorobenzene with chlorotrimethylsilane and $\mathrm{Mg}$. Then, 1,2-bis(trimethylsilyl)benzene was treated with $\mathrm{PhI}(\mathrm{OAc})_{2}$ activated with a double molar quantity of TfOH, and (Phenyl) [2-(trimethylsilyl)phenyl]iodonium triflate was obtained as crystal. The triflate was subjected to the benzyne-generating condition (1.5 eq BunF/THF/rt/2 days) in the presence of pyrrole to afford the cycloaddition 10. The product was subjected to preparative $\mathrm{TLC}\left(\mathrm{SiO}_{2}, \mathrm{CHCl}_{3}-\mathrm{MeOH}, 90: 10 \mathrm{v} / \mathrm{v} \%\right)$ and gave an unresolved 1:1 mixture of $\mathbf{1 0}$ and $\mathbf{1 1}(\delta 2.37,2.23$ for the bridgehead methyl group ${ }^{9}$ ). In case of phosphorylation of hydroxyl group 10, N,N-diisopropylphosphoamidite/tetrazole was reacted with 7-azabicyclo[2.2.1]hept2-ene for $14 \mathrm{~h}$ at room temperature. After this, $5.5 \mathrm{M}$ t-butyl hydroperoxide in nonane was added to reaction solution for $1 \mathrm{~h}$ to afford the phosphorylated 7-azabicyclo[2.2.1]hept-2ene 12. Benzyl groups of phosphate were removed using 

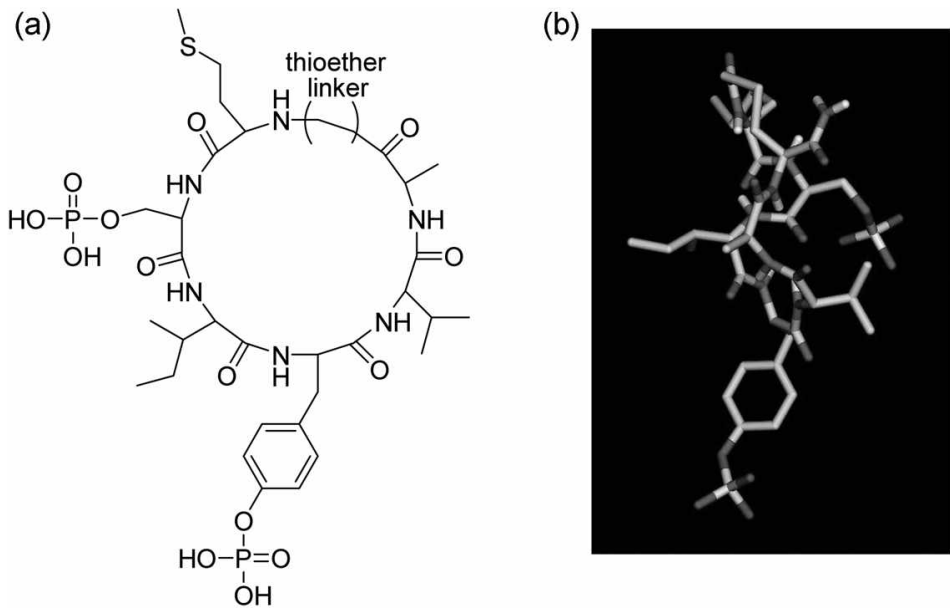

(c)

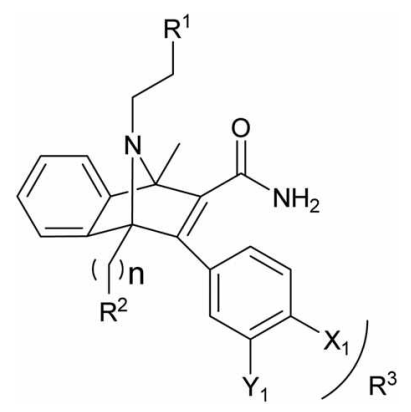

Figure 1. Chemical structure (A) and NMR-derived solution structure (B) of c(MpSIpYVA), 7-azabicyclo[2.2.1]hept-2-ene (C).

TFA/TIS/ $\mathrm{H}_{2} \mathrm{O}(95: 2.5: 2.5)$ for $2 \mathrm{~h}$. The ability of the 7 azabicyclo[2.2.1] hept-2-ene derivatives $\mathbf{1 3}$ as Wip I inhibitor was then measured using $30 \mu \mathrm{M}$ AFEEGpSQSTTI, which is known to Wipl substrate. The amount of phosphate was estimated using a malachite green/molybdate-based assay. ${ }^{10}$ The inhibitory activity of each-compound (A 1:1 mixture of the regioisomers) was evaluated using the corresponding $\mathrm{K}_{\mathrm{i}}$ value obtained from the sigmoidal dose-responsive curve. In Table 1 , the Wip1 inhibition constant $\left(\mathrm{K}_{\mathrm{i}}\right)$ is shown for 7 azabicyclo[2.2.1] hept-2-ene derivatives. From the preliminary results (Table 1), 7-azabicyclo[2.2.1] hept-2-ene derivatives 14-17 showed no detectable inhibition of Wipl except for compound 13. This compound has $\mathrm{K}_{\mathrm{i}}$ value $77 \mu \mathrm{M}$ even though this value is 20 -fold higher than cyclic peptide. According to this data, for the $\mathrm{R}^{1}$ position, aromatic, sulfone amide and phosphate group which mimics the phosphoserine residue of cyclic peptide were examined to see the structure-activity relationship (SAR). The assay result showed that phosphate group is best for this position. For $\mathrm{R}^{3}$ position, phenylphosphate group which mimics the phosphotyrosine of cyclic peptide is required to work as WipI inhibitor. For $\mathrm{R}^{2}$ position, ethyl side chain mimics the isoleucine in the cyclic peptide(in case of regioisomer, $\mathrm{R}^{\prime}$, $\mathrm{R}^{3}$ position corresponds to methyl group and amide group, respectively.)

In conclusion, small molecule inhibitor of Wip1 has been developed, indicating that Wipl is a good target for future drug development. It is our hope that these data will become the basis for development of future therapeutics to treat cancer.

\section{Experimental Section}

General. Materials were obtained from commercial suppliers and employed without further purification unless otherwise state. THF was distilled under $\mathrm{N}_{2}$ from sodium/ benzophenone immediately before use. All reactions were carried out under an argon atmosphere using dry solvents unless otherwise stated. Analytical thin-layer chromatography (TLC) was carried out on Whatman TLC plates precoated with silica gel $60(250 \mu \mathrm{m}$ layer thickness). Visualization of the plates was accomplished using either a UV lamp, iodine and/or ninhydrin stain followed by heating. Flash chromatography was performed on EM Science silica gel $60(230-400$ mesh). Solvent mixtures used for TLC, column chromatography and cleavage are reported in $v / v$ ratios. 'H NMR spectra spectra was recorded at $300 \mathrm{MHz}$ on a variant GEMINI-300 spectrometer (KBSI, Busan), using $\mathrm{CDCl}_{3}, \mathrm{DMSO}$ or $\mathrm{D}_{2} \mathrm{O}$ as solvent. Chemical shifts were reported in parts per million (ppm, $\delta$ ) relative to tetramethylsilane $(\delta 0.00)$. HPLC (Waters-2690, KBSI, Busan) was carried out on a reversed-phase column, which was eluted with $\mathrm{CH}_{3} \mathrm{CN}$ in $0.05 \%$ aqueous TFA and detected at $\mathrm{OD} 220$ nm.

Phosphatase Assay. Phosphatase activity was measured by a malachite green/molybdate-based assay. The $\mathrm{IC}_{50}$ values for inhibition of phosphatase activity by the phosphopeptide inhibitors were measured using $30 \mu \mathrm{M}$ AFEEGpSQSTTI substrate peptide (residues 1976-1986 in human ATM kinase) for $7 \mathrm{~min}$ at $30^{\circ} \mathrm{C}$ in $50 \mathrm{mM}$ Tris- $\mathrm{HCl}$, $\mathrm{pH} 7.5,0.1$ mM EGTA, 0.02\% 2-mercaptoethanol, $40 \mathrm{mM} \mathrm{NaCl}, 30$ $\mathrm{mM} \mathrm{MgCl}$. The phosphatase and phosphopeptide inhibitors were pre-equilibrated at $30^{\circ} \mathrm{C}$ for $6 \mathrm{~min}$. The inhibition percentages were estimated by equation $\mathrm{I}$.

$$
\text { Inhibition }(\%)=100\left[1-\left(A-A_{0}\right) /\left(A_{100}-A_{0}\right)\right]
$$

In equation $1, A$ and $A_{100}$ are absorbance intensities at 650 $\mathrm{nm}$ with or without the peptide inhibitor, respectively. $A_{0}$ is absorbance of the sample without phosphatase. The $\mathbf{I C}_{50}$ values were estimated by a sigmoidal dose-response equation. The apparent inhibitory constant $K_{\mathrm{i}}$ values were estimated using equation.

$$
K_{\mathrm{i}}=I C_{50} /\left(1+[\mathrm{S}] / K_{\mathrm{m}}\right)
$$

In equation $2,[S]$ is the concentration of the substrate peptide and $K_{\mathrm{m}}$ is the Michaelis constant.

\section{Synthesis of Wip1 Inhibitors}

$\beta$-Ketoamide resin 3: Rink amide resin 1 ( $0.5 \mathrm{~g}$, capacity: $0.6 \mathrm{mmol} / \mathrm{g}$ ) was suspended in DMF/piperidine $1: 1(5 \mathrm{~mL})$ and shaken for $45 \mathrm{~min}$. The resin was washed with DMF (2 

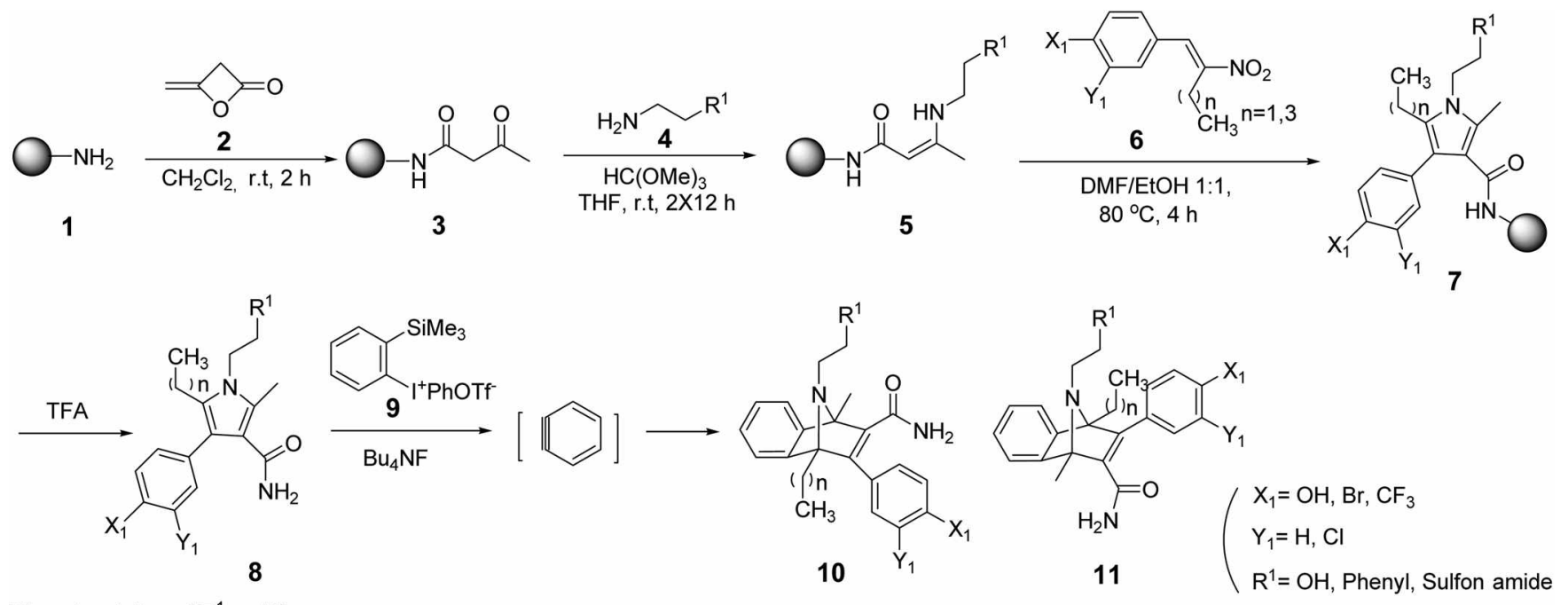

Phosphorylation of $\mathrm{R}^{1}$ and $\mathrm{X}_{1}$

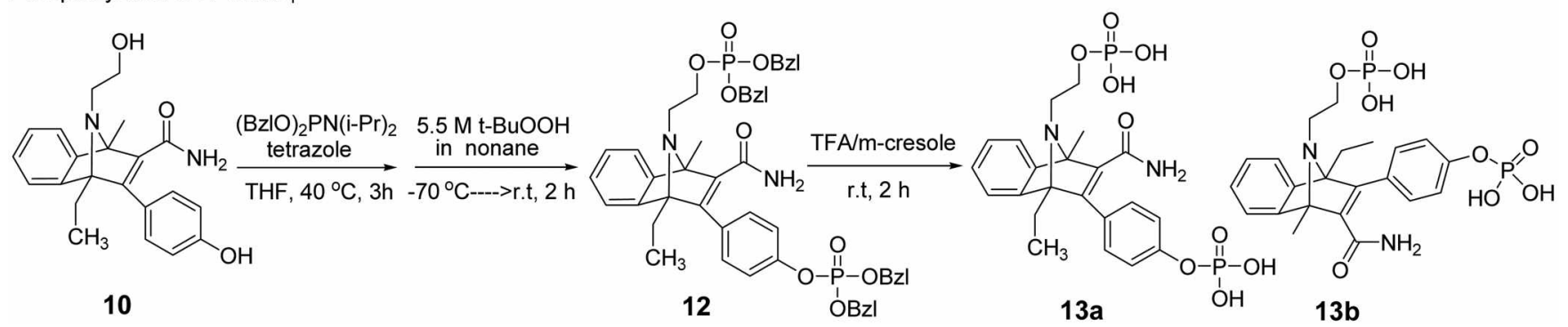

Scheme 1. Synthetic strategy to make 7-azabicyclo[2.2.1]hept-2-ene.

$\times 10 \mathrm{~mL})$, THF $(2 \times 10 \mathrm{~mL})$ and this step was repeated. The Kaiser ninhydrin test gave a positive result (blue color). The resin was suspended in THF $(10 \mathrm{~mL})$ and a diketene $(3.0$ mmol, 10 equiv.) was added. The reaction mixture was shaken at rt. After $4 \mathrm{~h}$, the resin was washed with THF $(3 \times 5$ $\mathrm{mL}), \mathrm{DCM}(3 \times 5 \mathrm{~mL}), \mathrm{Et}_{2} \mathrm{O}(3 \times 5 \mathrm{~mL})$ and dried under vacuum. The Kaiser ninhydrin test of $\mathbf{3}$ gave a negative result (colorless). This resin was used for the next step.

Enaminone resin $5\left(\mathbf{R}^{\prime}=\mathbf{O T r t}\right)$ : To a suspension of resin $3(0.5 \mathrm{~g}, 0.3 \mathrm{mmol}, 1.0$ equiv. $)$ in THF $(3 \mathrm{~mL})$ were added trimethylorthoformate $(0.3 \mathrm{~mL}, 3 \mathrm{mmol}, 10$ equiv.) and a trityl-protected aminoethanol $(0.9 \mathrm{~g}, 3 \mathrm{mmol}, 10$ equiv. $)$ at $25^{\circ} \mathrm{C}$. The reaction mixture was stirred for $12 \mathrm{~h}$, then the resin was washed with THF $(3 \times 5 \mathrm{~mL})$ and this step was repeated once more. The reaction mixture was washed successively with THF $(3 \times 5 \mathrm{~mL})$, DCM $(3 \times 5 \mathrm{~mL})$ and $\mathrm{Et}_{2} \mathrm{O}(3 \times 5 \mathrm{~mL})$ and dried under high vacuum. This resin was used for the next step.

Pyrrole synthesis on the solid support $7\left(\mathrm{R}^{\prime}=\mathrm{OH}, n=1\right.$, $\left.\mathbf{X}_{\mathbf{H}}=\mathbf{O H}, \mathbf{Y}_{\mathbf{I}}=\mathbf{H}\right)$ : To a suspension of enaminone resin $\mathbf{5}(0.5$ $\mathrm{g}, 0.3 \mathrm{mmol}, 1.0$ equiv.) in DMF/EtOH $1: 1(5 \mathrm{~mL})$ was added a nitroalkene (in this case, $(E)$-2-chloro-4-(2-nitrobut1-enyl)phenol $(0.43 \mathrm{~g}, 1.5 \mathrm{mmol}$, 5 equiv). The reaction mixture was stirred at $80^{\circ} \mathrm{C}$ for $4 \mathrm{~h}$, after which the resin was filtered, washed successively with DMF $(3 \times 5 \mathrm{~mL})$, $\mathrm{DCM}(3 \times 5 \mathrm{~mL})$ and $\mathrm{Et}_{2} \mathrm{O}(3 \times 5 \mathrm{~mL})$ and dried under high vacuum.

The resin $(0.1 \mathrm{~g}, 0.06 \mathrm{mmol})$ was treated with TFA $(4 \mathrm{~mL})$ in the presence of triisopropylsilane $(0.1 \mathrm{~mL})$ at room temperature for $1 \mathrm{~h}$. After evaporation of TFA, $\mathrm{CHCl}_{3}(5$ $\mathrm{mL}$ ) was added to the reaction vessel. The organic layer was washed with aqueous $\mathrm{NaHCO}_{3}(3 \mathrm{~mL})$ and dried $\left(\mathrm{MgSO}_{4}\right)$. Purification of the crude product by preparative thin layer chromatography (silica gel $\mathrm{CHCl}_{j}-\mathrm{MeOH} 9: 1, \mathrm{R}_{f} 0.33$ ) gave, in this case, 8 (minus the Trt-protecting group) as a colorless oil. HNMR: (300 MHz, DMSO) $\delta 7.95(\mathrm{~s}, 1 \mathrm{H}), 7.02$ (d, $J=$ $8.4 \mathrm{~Hz}, 2 \mathrm{H}), 6.78$ (d, $J=7.2 \mathrm{~Hz}, 2 \mathrm{H}), 5.42$ (br s, $1 \mathrm{H}), 4.96$ (br s, $1 \mathrm{H}), 3.91$ (t, $J=6.3 \mathrm{~Hz}, 2 \mathrm{H}$ ), 3.57 (t, $J=7.5 \mathrm{~Hz}, 2 \mathrm{H}$ ), $2.90(\mathrm{~s}, 3 \mathrm{H}), 2.40-2.36(\mathrm{~m}, 2 \mathrm{H}), 0.99(\mathrm{t}, J=7.2,8.4 \mathrm{~Hz}, 3 \mathrm{H})$; ESI-MS, $m / z 289.15$ for $[\mathrm{M}+\mathrm{H}]^{+}$(calcd for $\mathrm{C}_{16} \mathrm{H}_{21} \mathrm{~N}_{2} \mathrm{O}_{3}$ 289.34).

7-Azabicyclo-[2.2.1] hep-2-ene synthesis 10 and 11: To a solution of (phenyl)-[2-(trimethylsilyl)phenyl]iodonium triflate $(0.502 \mathrm{~g}, 1.0 \mathrm{mmol})$ and pyrrole $(0.34 \mathrm{~g}, 5.0 \mathrm{mmol})$ in $\mathrm{CH}_{2} \mathrm{Cl}_{2}(3 \mathrm{~mL})$ was added dropwise a THF solution of $B u_{4} N F(1.0 \mathrm{M}, 1.2 \mathrm{~mL})$ at $0{ }^{\circ} \mathrm{C}$, and the reaction mixture was stirred at room temperature for $14 \mathrm{~h}$. Then, water was added and the resulting mixture was extracted with $\mathrm{CH}_{2} \mathrm{Cl}_{2}$. The organic extracts were dried over anhydrous $\mathrm{Na}_{2} \mathrm{SO}_{4}$ and concentrated. Purification of the crude product by preparative thin layer chromatography (silica gel $\mathrm{CHCl}_{3}-\mathrm{MeOH}$ 9:1, $\mathrm{R}_{f} 0.41$ ) gave free $\mathbf{1 0}$ and $\mathbf{1 1}$ as a colorless oil. An unresolved 1:1 mixture of $\mathbf{1 0}$ and 11. 'H NMR: (300 MHz, DMSO) $\delta 7.65-7.24(\mathrm{~m}, 10 \mathrm{H}), 7.02-6.76(\mathrm{~m}, 6 \mathrm{H}), 3.4 \mathrm{I}-3.19$ $(\mathrm{m}, 8 \mathrm{H}), 2.19$ (br s, 6H), $1.79-1.70(\mathrm{~m}, 2 \mathrm{H}), 1.58(\mathrm{q}, J=6.3$ $\mathrm{Hz}, 2 \mathrm{H}), 1 . \mathrm{l}(\mathrm{t}, J=7.2,8.4 \mathrm{~Hz}, 6 \mathrm{H}$ ); ESI-MS, $m / z 365.2$ for $[\mathrm{M}+\mathrm{H}]^{\circ}$ (calcd for $\mathrm{C}_{22} \mathrm{H}_{25} \mathrm{~N}_{2} \mathrm{O}_{3} 365.4$ ).

Phosphitylation and oxidation 12: In a flask was dis- 
Table 1. The reaction of Benzyne with pyrrole derivatives

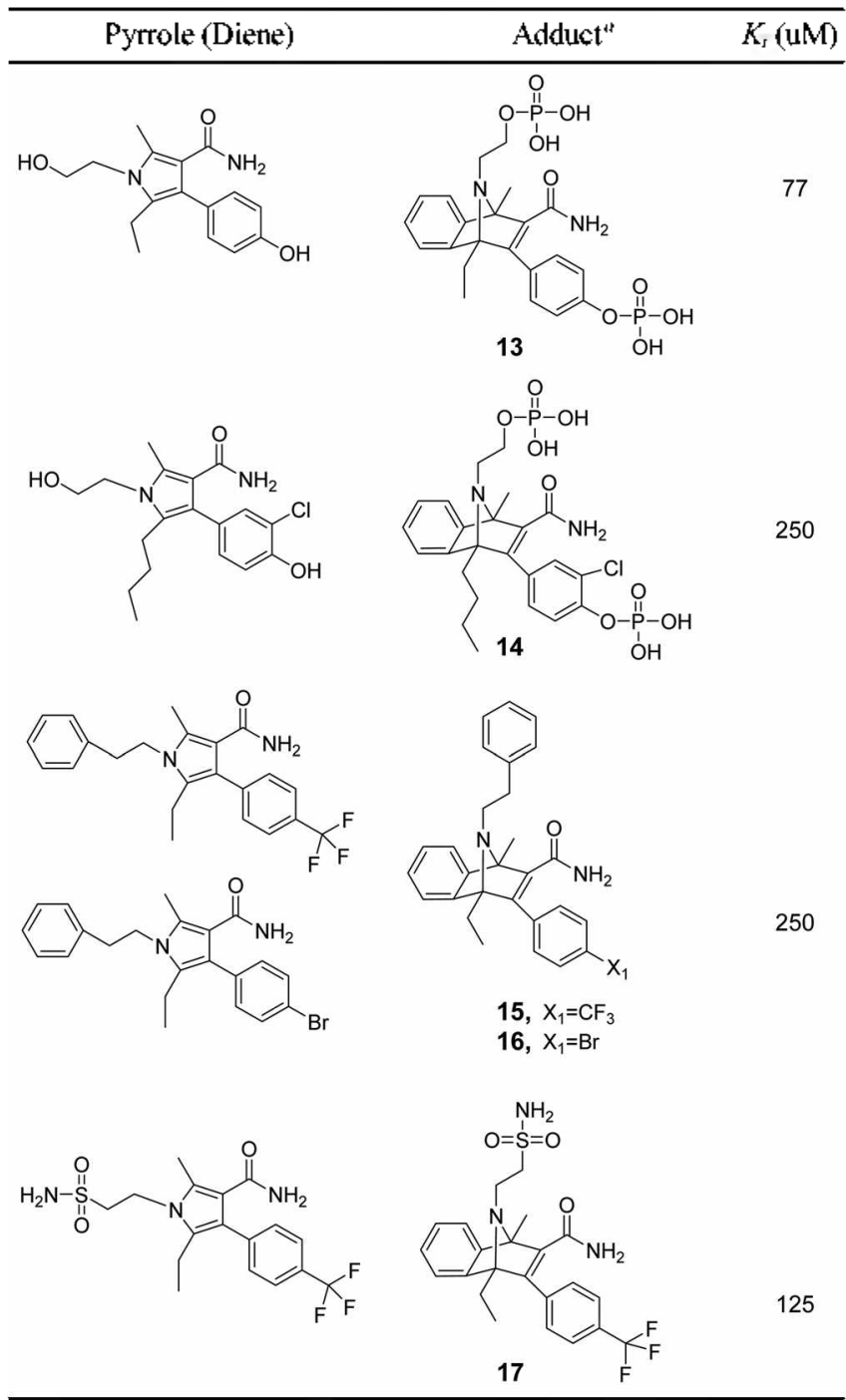

"All compounds are unresolved 1:1 mixture of regioisomers

solved $1 H$-tetrazole $(2.0 \mathrm{~mL}, 1.0 \mathrm{mmol}, 10$ equiv.) in THF ( 2 $\mathrm{mL}$ ) followed by dibenzyl- $N, N$-diisopropylphosphoramidite $(0.2 \mathrm{~mL}, 1.0 \mathrm{mmol}, 10$ equiv.). After $5 \mathrm{~min}$, the mixture was added to compound $10(0.2 \mathrm{~g}, 0.1 \mathrm{mmol})$ in THF $(5 \mathrm{~mL})$ and the mixture was stirred at $40^{\circ} \mathrm{C}$ for $3 \mathrm{~h}$. After this time, the reaction mixture was cooled to $0^{\circ} \mathrm{C}$ using ice bath.

To a stirred solution of this compound $(0.2 \mathrm{~g}, 0.1 \mathrm{mmol})$ in THF $(3 \mathrm{~mL})$ was added $5.5 \mathrm{M}-t$-butyl hydroperoxide in nonane $(0.5 \mathrm{~mL}, 2.5 \mathrm{mmol}, 25$ equiv.) and the mixture was stirred at $25^{\circ} \mathrm{C}$ for $1 \mathrm{~h}$. After this time, the resulting mixture was dilute with ethyl acetate $(50 \mathrm{~mL})$. The organic layer was washed with aqueous $\mathrm{NaHCO}_{3}(3 \mathrm{~mL})$ and dried $\left(\mathrm{MgSO}_{4}\right)$. Purification of the crude product by preparative thin layer chromatography (silica gel ethyl acetate-hexane $5: 1, \mathbb{R}, 0.21$ ) gave 12 as a colorless oil. 'H NMR: $\left(300 \mathrm{MHz}, \mathrm{CDCl}_{3}\right) \delta$ 7.35-7.20 (m, 22H), 7.12-7.04 (m, 4H), 6.88-6.86 (d, $J=8.4$ $\mathrm{Hz}, 2 \mathrm{H}), 5.13-4.96(\mathrm{~m}, 8 \mathrm{H}), 4.31-4.29(\mathrm{~m}, 2 \mathrm{H}), 4.20-4.17$ $(\mathrm{m}, 2 \mathrm{H}), 1.85(\mathrm{~s}, 3 \mathrm{H}), 1.27-1.22(\mathrm{~m}, 2 \mathrm{H}), 0.93-0.88(\mathrm{~m}, 3 \mathrm{H})$; ESI-MS, $m / z 885.2$ for $[\mathrm{M}+\mathrm{H}]^{+}$(calcd for $\mathrm{C}_{50} \mathrm{H}_{51} \mathrm{~N}_{2} \mathrm{O}_{9} \mathrm{P}_{2}$ 885.2).

Deprotection of benzyl group of phosphate 13: The compound $12(0.2 \mathrm{~g}, 0.1 \mathrm{mmol})$ was treated with $\mathrm{TFA} / \mathrm{m}$ cresol $(95 / 5=\mathrm{v}: \mathrm{v})(5 \mathrm{~mL})$ at $25^{\circ} \mathrm{C}$ for $3.5 \mathrm{~h}$. After evaporation of TFA, diethyl ether $(15 \mathrm{~mL})$ was added to the reaction vessel. The resulting precipitate was washed with diethyl ether $(10 \mathrm{~mL})$ and dissolved in $0.1 \%$ aqueous TFA. The solution was freeze-dried and the crude product was purified by preparative HPLC to give the final 7-azabicyclo[2.2.1]hept-2-ene as a white powder 13a and 13b. All products were purified by reverse phase HPLC.

HPLC; $17.33 \mathrm{~min}$ [Agilent Eclipse XOB-C18 column (4.6 $\times 250 \mathrm{~mm}), 1.0 \mathrm{~mL} / \mathrm{min}, \mathrm{CH}_{3} \mathrm{CN}(0 \%$ to $\left.60 \%, 30 \mathrm{~min})\right]$, An unresolved 1:I mixture of 13a and 13b; ${ }^{1} \mathrm{H}$ NMR: $(300$ $\left.\mathrm{MHz}, \mathrm{D}_{2} \mathrm{O}\right) \delta 7.68-7.55(\mathrm{~m}, 4 \mathrm{H}), 7.45-7.42(\mathrm{~m}, 4 \mathrm{H}), 7.26-$ $7.22(\mathrm{~m}, 6 \mathrm{H}), 7.12(\mathrm{~d}, J=8.4 \mathrm{~Hz}, 2 \mathrm{H}), 4.31-4.29(\mathrm{~m}, 2 \mathrm{H})$, $4.20-4.17(\mathrm{~m}, 2 \mathrm{H}), 3.95-3.78(\mathrm{~m}, 4 \mathrm{H}), 2.37(\mathrm{~s}, 3 \mathrm{H}), 2.23$ $(\mathrm{s}, 3 \mathrm{H}), 1.19(\mathrm{t}, J=7.2 \mathrm{~Hz}, 3 \mathrm{H}), 1.03(\mathrm{t}, J=7.2 \mathrm{~Hz}, 3 \mathrm{H})$; ESI-MS, $m / z 523.1$ for $[\mathrm{M}-\mathrm{H}]^{-}$(calcd for $\mathrm{C}_{22} \mathrm{H}_{25} \mathrm{~N}_{2} \mathrm{O}_{9} \mathrm{P}_{2}$ $523.2)$.

Acknowledgments. This work was supported by KBSI project N28079.

\section{References}

I. (a) Fiscella, M.; Zhang, H.; Sakaguchi, K.; Shen, S.; Mercer, W. E.; Woude, G. F. V.; O'Connor, P. M.; Appella, E. Proc. Natl. Accd. Sci. USA 1997, 04, 6048-6053. (b) Bulavin, D. V.; Saito, S. I.; Hollander, M. C.; Sakaguchi, K.; Anderson, C. W.; Appella, E.; Fornace, A. J. Jr. EMBO J. 1999, J8, 6845-6854. (c) SanchezPrielo, R.; Rojas, J. M.; Taya, Y,; Gutkind, J. S. Cancer Res, 2000, $60,2464-2472$.

2. Takegawa, M.; Adachi, M.; Nakahata, A.; Nakayama, I.; Itoh, F.; Tsukusa, H.; Taya, Y.; Imai, K. EMBO J. 2000, 19, 6517-6536.

3. (a) Bulavin, D. V;; Demidov, O. N.; Saito, S. J.; Kauraniemi, P.; Phillips, C.; Amundson, S. A.; Ambrosino, C.; Sauter, G; Nebreda, A. R.; Anderson, C. W.; Kallioniemi, A.; Fornace, A. J., Jr.; Appella, E. Nature Genetics 2002, 3I, 210-215. (b) Hirasawa, A.; Saito-Ohara, F.; Inoue, J.; Aoki, D.; Susumu, N.; Yokoyama. T.; Nozawa, S.; Imoto, I. Clic. Can. Res. 2003, 9, 1995-2004.

4. Yamaguchi, H.; Durell, S. R.; Feng. H.; Bai, Y.; Anderson, C. W.; Appella, E. Biochemistry 2006, 45, 13193-13202.

5. Nishide, K.; Ichihashi, S.; Kimura, H.; Katoh, T.; Node, M. Tetrahedron Lett. 2001, 42, 9237-9240.

6. (a) Meyer, H. Liebigs Amm. Chen. 1981, 1534-1544. (b) Trautwein, A. W.; Jung, G. Terahedron Lett. 1998, 39, 8263-8266.

7. The Chemistn of the Heterocyclic Compounds: Pyroles; Jones, R. A., Ed.; Wiley \& Sons: New York, 1990; Vol, 48, pp 40l-410.

8. Caster, K.; Keck, C. G; Walls, R. D. J. Org. Chem, 2001, 66 , $2932-2936$

9. (a) Kitamura, T.; Yamane, M.; Inoue, K.; Todaka, M.; Fukatsu, N.; Meng, Z.; Fujiwara, Y. J. Am. Chem. Soc. 1999, J21, 11679. (b) Shakaran, K.; Snieckus, V. Tetrahedron Lett. 1984, 25, 2827-2830.

10. Yamaguchi, H.; Minopoli, G; Demidov, O. N.; Chaterjee, D. K.; Anderson, C. W.; Durell, S. R.; Appella, E. Biochemistry 2005, $44,5285-5294$. 